\title{
Diagnosis dan Penatalaksanaan Abses Septum Nasi
}

Bestari J Budiman, Jon Prijadi

\begin{abstract}
Abstrak
Abses septum nasi adalah terkumpulnya pus di antara tulang rawan dengan mukoperikondrium atau tulang septum dengan mukoperiosteum yang melapisinya. Abses septum dapat menyebabkan hidung pelana bahkan komplikasi intrakranial, sehingga diperlukan diagnosis dan tindakan yang tepat dan cepat.

Telah dilaporkan satu kasus abses septum pada wanita umur 34 tahun dan telah dilakukan insisi dan eksplorasi abses dalam narkose umum.Kata kunci: Arial 9 Kata Kunci: Abses septum nasi, hematoma septum, hidung pelana.
\end{abstract}

\begin{abstract}
Nasal septal abscess is defined as pus accumulation between cartilage and mucopericondrium or septal bone and mucoperiosteum which is layer it. Septal abscess can cause saddle nose even intracranial complications, requiring additional diagnosis and appropriately and quickly management. Reported one case of septal abscess in woman 34 years old and has been done the abscess incision and exploration in general anaesthesia.
\end{abstract}

Keywords:Nasal septal abscess, haematoma septum, saddle nose.

Affiliasi penulis : Bagian THT-KL fakultas Kedokteran universitas Andalas

Korespondensi :Bestari J Budiman, Bagian THT-KL Fakultas

Kedokteran Universitas Andalas, Padang

\section{PENDAHULUAN}

Abses septum nasi adalah pus yang terkumpul di antara tulang rawan dengan mukoperikondrium atau tulang septum dengan mukoperiosteum yang melapisinya. Kasus ini sangat jarang ditemukan sehingga sangat sedikit dibicarakan dalam berbagai kepustakaan.

Abses septum biasanya didahului oleh trauma hidung yang kadang-kadang sangat ringan sehingga tidak dirasakan oleh penderita, akibatnya timbul hematoma septum yang bila terinfeksi akan menjadi abses. ${ }^{1}$ Pada umumnya, abses septum nasi yang besar, terasa nyeri dan mukosa mengalami inflamasi dan ditutupi oleh eksudat. $^{1,2}$

Abses septum dapat berakibat serius pada hidung oleh karena menyebabkan nekrosis kartilago septum yang kemudian menjadi destruksi dan lambat laun menjadi hidung pelana. Komplikasi yang sangat berbahaya berupa infeksi intrakranial sehingga setiap abses septum nasi harus dianggap sebagai kasus emergensi yang memerlukan penanganan yang tepat dan segera. ${ }^{3}$

\section{KEKERAPAN}

Abses septum merupakan kasus yang jarang ditemukan. Dikutip dari Jalaludin, ${ }^{4}$ Eavei mendapatkan 3 kasus abses septum nasi dalam waktu 10 tahun terakhir di Children's hospital Los Angeles. Fearon ${ }^{4}$ mendapatkan 43 kasus abses septum nasi dalam periode 8 tahun di Hospital for Sick Children di Toronto. Dikutip oleh Jalaluddin, Ambrus menyatakan pada dekade terakhir ini didapatkan hanya 14 kasus abses septum nasi, termasuk 16 kasus yang terjadi lebih dari periode 10 tahun di Massachusetts Eye and Ear Infirmary. Di Rumah Sakit M.DJamil Padang didapatkan 3 kasus abses septum nasi dalam waktu 2 tahun terakhir.

Usia yang paling sering terkena adalah di bawah 15 tahun diikuti usia 16-31 tahun dan jarang usia lanjut. Laki-laki lebih sering dibandingkan wanita. $\mathrm{Hal}$ ini dihubungkan dengan agresivitas dan aktivitas mereka sehingga insidens trauma mudah terjadi. ${ }^{5}$

\section{ANATOMI SEPTUM NASI}

Septum membagi kavum nasi menjadi 2 ruang, kanan dan kiri. Septum nasi dibentuk oleh tulang dan tulang rawan. Septum nasi dilapisi oleh perikondrium pada bagian tulang rawan dan periosteum pada bagian tulang, sedangkan diluarnya dilapisi oleh mukosa hidung. ${ }^{6,7}$

Bagian tulang rawan adalah kartilago septum nasi (lamina kuadrangularis) dan kolumela.

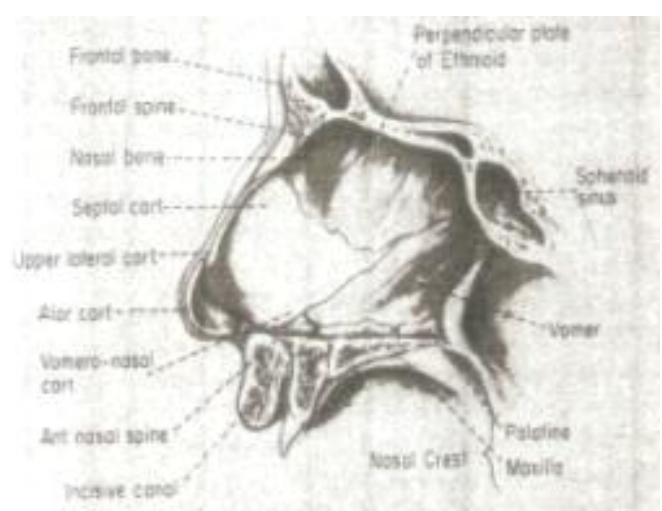

\section{Gambar1: Anatomi Septum nasi ${ }^{ð}$}

Bagian tulang yang membentuk septum nasi terdiri dari 1)Kartilago kuadrangularis 2) Lamina perpendikularis os ethmoid 3) Os vomer 4) Krista nasalis maksila. $^{7}$

Septum nasi terletak pada tulang penyangga yang terdiri dari (ventral ke dorsal) spina nasal anterior, premaksila, dan vomer. Pada bagian kaudal, kartilago septum nasi bebas bergerak dan berhubungan dengan kolumela oleh membran septum nasi. Pada bagian dorsal bersatu dengan lamina perpendikularis os ethmoid. Pada bagian Ventral, berhubungan dengan dua kartilago triangularis (kartilago lateral atas), dan bersama-sama membentuk kartilago vault dan batang hidung. ${ }^{7}$ 
Bagian tulang septum nasi terdiri dari lamina perpendikularis os ethmoid, premaksilaris dan vomer yang merupakan perluasan dari rostrum sphenoid. ${ }^{7}$ Kerangka tulang rawan dari septum nasi dan kartilago lateral atas yang berbentuk "T" memberi kekuatan yang cukup untuk menahan tekanan dari tulang di sekitarnya. Kartilago kuadrangularis adalah bagian medial kerangka T hidung. Kaudal hidung sampai di daerah inferior septum nasi terletak pada krista maksilaris dan diikat oleh perikondrium dan periosteum. ${ }^{7}$ Reseksi atau destruksi dari tulang rawan tersebut akibat trauma atau operasi pengangkatan kartilago kuadrangularis yang berlebihan akan mengakibatkan bentuk hidung seperti pelana. ${ }^{6,7}$

\section{PERDARAHAN}

Bagian anterosuperior septum nasi dan dinding lateral memperoleh perdarahan dari arteri ethmoidalis anterior dan posterior, sedangkan bagian posteroinferior septum nasi memperoleh dari arteri sfenopalatina dan arteri maksilaris interna.

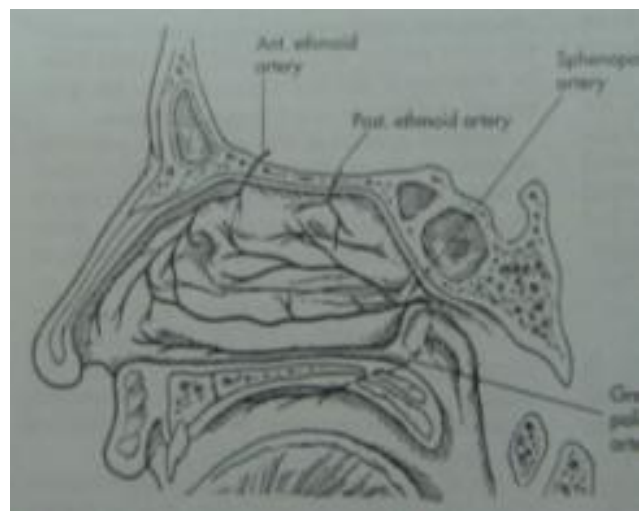

Gambar 2 : Vaskularisasi Hidung. ${ }^{6}$

Pada bagian kaudal septum nasi terdapat pleksus Kiesselbach yang terletak tepat di belakang vestibulum. Pleksus ini merupakan anastomosis dari arteri sfenopalatina, arteri etmoidalis anterior, arteri palatina mayor. Area ini paling sering menjadi sumber perdarahan atau epistaksis.

\section{PERSARAFAN}

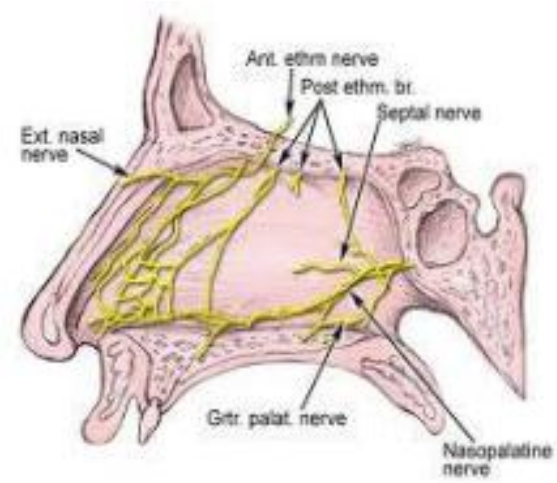

Gambar 3 : Persarafan Hidung. ${ }^{๖}$

Bagian anterosuperior hidung bagian dalam dipersarafi oleh n.etmoidalis anterior dan posterior, sedangkan cabang dari $\mathrm{n}$. maksilaris dan ganglion pterigopalatina mempersarafi bagian posterior dan sensasi pada bagian anteroinferior septum nasi dan dinding lateral. ${ }^{7,8,9}$

\section{ETIOLOGI DAN PATOGENESIS}

Penyebab abses septum nasi tersering adalah trauma hidung akibat kecelakaan, perkelahian, olah raga ataupun trauma yang sangat ringan sehingga tidak dirasakan penderita seperti mengorek kotoran hidung atau mencabut bulu hidung. ${ }^{1,3}$ Dispenza $^{10}$ memberikan istilah pada supurasi septum akibat trauma sebagai abses septum primer, sedangkan penyebab lainnya dianggap sebagai abses septum nasi sekunder. Abses septum nasi dapat terjadi secara spontan pada pasien sindrom imunodefisiensi didapat. $^{11}$

Abses septum nasi dapat terjadi akibat furunkel intranasal, peradangan sinus, akibat komplikasi operasi hidung dan penyakit sistemik. ${ }^{10,11}$ Abses septum nasi hampir selalu didahului oleh hematoma septum nasi yang terinfeksi. ${ }^{2,8.9}$ Dikutip dari Dirk, ${ }^{11}$ Da silva melaporkan bahwa infeksi gigi dapat menimbulkan abses septum.

Hematoma septum nasi terjadi akibat trauma pada septum nasi yang merobek pembuluh darah yang berbatasan dengan tulang rawan septum nasi. ${ }^{12}$ Darah akan terkumpul pada ruang di antara tulang rawan dan mukoperikondrium. Hematoma ini akan memisahkan tulang rawan dari mukoperikondrium, sehingga aliran darah sebagai nutrisi bagi jaringan tulang rawan terputus, maka terjadilah nekrosis. ${ }^{11,12}$

Tulang rawan septum nasi yang tidak mendapatkan aliran darah masih dapat bertahan hidup selama 3 hari, setelah itu kondrosit akan mati dan resorpsi tulang rawan akan terjadi. ${ }^{12}$ Bila tidak segera ditanggulangi, maka tulang septum nasi dan triangular kartilago dapat ikut terlibat dan perforasi septum nasi dapat terjadi. Pada akhirnya sedikit atau banyak akan terjadi parut dan hilangnya penyangga pada 2/3 kaudal septum, ini akan menghasilkan hidung pelana, retraksi kolumella, dan pelebaran dasar hidung. ${ }^{13,14}$

Jika ada fraktur tulang rawan, maka darah akan mengalir ke sisi kontralateral dan terjadilah hematom septum bilateral. ${ }^{15}$ Hematom yang terjadi dapat besar sehingga dapat menyumbat kedua nares. ${ }^{11,16}$ Akibat keadaan yang relatif kurang steril di bagian anterior hidung, hematoma septum nasi dapat terinfeksi dan akan cepat berubah menjadi abses septum nasi yang mempercepat resorpsi tulang rawan yang nekrotik. 7,11

Staphylococcus aureus merupakan organisme yang paling sering ditemukan pada hasil kultur abses septum nasi. Begitu pula Streptococcus pneumoniae, streptococcus milleri, Streptococcus viridians, Staphylococcus epidermis, Haemophillus influenza dan kuman anaerob juga ditemukan pada abses septum nasi. ${ }^{12}$

Tidak semua hematom septum nasi berkembang menjadi abses, bila sembuh dengan terapi antibiotik akan terbentuk jaringan ikat, sehingga akan terjadi penebalan jaringan septum nasi yang dapat menyebabkan obstruksi saluran nafas dan retraksi yang menimbulkan kontraktur septum nasi. ${ }^{12}$ Bila keadaan ini terjadi pada masa anak-anak, akan mempengaruhi pertumbuhan $2 / 3$ bagian wajah yang dapat menyebabkan hipoplasia maksila. ${ }^{11,12}$ Infeksi pada septum nasi dapat masuk ke dalam sinus kavernosus sehingga akan terjadi trombosis dan atau meningitis. $^{13}$

\section{DIAGNOSIS}

Diagnosis dapat ditegakkan berdasarkan anamnesis dan pemeriksaan fisik. Sebagian besar 
abses septum nasi biasanya mempunyai riwayat trauma, kadang-kadang penderita tidak menyadari terjadinya trauma tersebut. Trauma septum nasi dan mukosa dapat terjadi tanpa adanya cedera hidung luar. Abses septum nasi sering timbul 24-48 jam setelah trauma, terutama pada dewasa muda dan anak. $^{7}$

Gejala abses septum nasi adalah hidung tersumbat yang progresif disertai rasa nyeri. Rasa nyeri terutama dirasakan di daerah dorsum nasi terutama di puncak hidung. ${ }^{12,13}$ Juga terdapat keluhan demam dan sakit kepala. Perlu ditanyakan riwayat operasi hidung sebelumnya, gejala peradangan hidung dan sinus paranasal, furunkel intra nasal, penyakit gigi dan penyakit sistemik. ${ }^{14}$

Akibat trauma hidung, terkadang pada inspeksi masih tampak kelainan berupa eskoriasi, laserasi kulit, epistaksis, deformitas hidung, edema dan ekimosis. ${ }^{14}$ Pemeriksaan sebaiknya tanpa menggunakan spekulum hidung. Tampak pembengkakan septum berbentuk bulat dengan permukaan licin pada kedua sisi. ${ }^{13,14}$

Identifikasi abses septum nasi sangat mudah bagi para ahli, tetapi tidak jarang dokter gagal dalam mengamati keadaan ini. $^{12}$ Karena kegagalan dalam mengidentifikasi hematoma atau abses septum nasi cukup banyak, maka diperlukan pemeriksaan intra nasal yang teliti. Jika penderita tidak kooperatif, misalnya pada anak-anak, pemeriksaan dapat dilakukan dengan anestesi umum. ${ }^{15}$

Pada pemeriksaan rinoskopi anterior, seluruh septum nasi harus diperiksa dari kaudal septum nasi sampai nasofaring. ${ }^{12,15}$ Tampak pembengkakan unilateral ataupun bilateral, mulai tepat di belakang kolumella meluas ke posterior dengan jarak bervariasi. ${ }^{16}$

Perubahan warna menjadi kemerahan atau kebiruan pada daerah septum nasi yang membengkak menunjukkan suatu hematoma. ${ }^{12,14}$ Daerah yang dicurigai dipalpasi dengan forsep bayonet atau aplikator kapas untuk memeriksa adanya fluktuasi dan nyeri tekan. Pada palpasi dapat ditemukan nyeri tekan. ${ }^{11,12}$

Untuk memastikan abses septum nasi cukup dengan aspirasi pada daerah yang paling fluktuasi. Pada aspirasi akan didapatkan pus pada abses septum nasi, sedangkan dari hematoma septum nasi akan keluar darah. ${ }^{12}$

Beberapa penulis menyarankan tindakan rutin berupa aspirasi sebelum diberikan tindakan operatif. $^{12,13}$ Pus yang diperoleh sebaiknya diperiksakan di laboratorium untuk menentukan jenis kuman dan tes sensitifitas terhadap antibiotik. ${ }^{2,3,9,12}$ Selain bernilai diagnostik, aspirasi juga berguna untuk mengurangi ketegangan jaringan di daerah abses septum nasi dan mengurangi kemungkinan komplikasi ke intrakranial. .,10,12 $^{2}$

Pemeriksaan laboratorium darah akan menunjukkan leukositosis. ${ }^{7,14}$ Pemeriksaan foto rontgen sinus paranasal atau CT scan harus dilakukan untuk mencari etiologi ataupun komplikasi. ${ }^{15,17}$

\section{PENATALAKSANAAN}

Hematoma atau abses septum nasi harus dianggap sebagai kasus darurat dalam bidang THT dan tindakan penanggulangannya harus segera dilakukan untuk mencegah komplikasi. Penatalaksanaan abses septum nasi yang dianjurkan saat ini yaitu drainase, antibiotik parenteral dan rekonstruksi defek septum. Tujuan dari rekonstruksi adalah untuk menyangga dorsum nasi, memelihara keutuhan dan ketebalan septum, mencegah perforasi septum yang lebih besar dan mencegah obstruksi nasal akibat deformitas. ${ }^{17,18,19}$

Insisi dan drainase abses septum nasi dapat dilakukan dalam anestesi lokal atau anestesi umum. Sebelum insisi terlebih dahulu dilakukan aspirasi abses dan dikirim ke laboratorium untuk pemeriksaan kultur dan tes sensitifitas. ${ }^{2,12}$

Insisi dilakukan $2 \mathrm{~mm}$ dari kaudal kartilago kira-kira perbatasan antara kulit dan mukosa (hemitransfiksi) atau caudal septal incision (CSI) pada daerah sisi kiri septum nasi. ${ }^{3}$ Septum nasi dibuka secara perlahan-lahan tanpa merusak mukosa. Jaringan granulasi, debris dan kartilago yang nekrosis diangkat dengan menggunakan kuret dan suction. Sebaiknya semua jaringan kartilago yang patologis diangkat. Dilakukan pemasangan tampon anterior dan pemasangan salir untuk mencegah rekurensi. ${ }^{11,12}$

Drainase bilateral merupakan kontraindikasi karena dapat menyebabkan perforasi septum nasi. Pada abses bilateral atau nekrosis dari tulang rawan septum nasi dianjurkan untuk segera melakukan eksplorasi dan rekonstruksi septum nasi dengan pemasangan implan tulang rawan. ${ }^{18,19}$

\section{KOMPLIKAS}

Deformitas dan gangguan fungsi hidung akibat abses septum nasi dapat dibedakan dalam tiga proses di bawah ini. 1.Hilangnya sanggahan mekanik dari kartilago piramid dan lobul 2.Retraksi dan atrofi jaringan ikat 3.Gangguan pertumbuhan hidung dan muka bagian tengah. ${ }^{12,14}$

Selain kosmetik, abses septum nasi dapat juga menimbulkan komplikasi yang berat dan berbahaya bila terjadi penjalaran infeksi ke intrakranial berupa meningitis,abses otak dan empiema subaraknoid. ${ }^{1,2,12}$

Penjalaran ke intrakranial dapat melalui berbagai jalan. Pertama melalui pembuluh-pembuluh vena dari segitiga berbahaya, yaitu daerah di dalam garis segitiga dari glabela ke kedua sudut mulut. Vena-vena tersebut melalui vena angularis, vena oftalmika, vena etmoidalis, yang akan bermuara di sinus kavernosus. ${ }^{2}$

Kedua, infeksi masuk melalui mukosa hidung kemudian melalui pembuluh limfe atau pembuluh darah bermuara di sinus longitudinal dorsalis dan sinus lateralis. Ketiga, melalui saluran limfe dari meatus superior melalui lamina kribriformis dan lamina perpendikularis os etmoid yang bermuara ke ruang subaraknoid. Keempat, invasi langsung dapat terjadi pada saat operasi, erosi lokal diduga dapat juga merupakan jalan atau kebetulan ada kelainan kongenital. Kelima, selubung perineural diduga dapat juga merupakan jalannya penjalaran infeksi, dalam hal ini selubung olfaktorius yang menuju intrakranial melalui lamina kribriformis. ${ }^{2,11,12,14}$

Penjalaran infeksi ke

organ-organ di sekitar hidung dapat juga melalui saluran limfe dan selubung saraf olfaktorius sehingga terjadi infeksi ke orbita dan sinus paranasal. ${ }^{8,12}$

Keterlambatan diagnosis dapat menyebabkan destruksi tulang rawan dan tulang hidung sehingga terjadi deformitas yang berupa hidung pelana,retraksi kolumella,dan pelebaran dasar hidung. Nekrosis pada setiap komponen septum nasi dapat menyebabkan terjadinya perforasi septum nasi. ${ }^{12,18,19}$ 


\section{LAPORAN KASUS}

Seorang pasien wanita berusia 34 tahun. Datang ke RSUP Dr. M.Djamil Padang pada tanggal 16 Februari 2010 rujukan dari RSUD Kerinci dengan diagnosis polip nasi. Keluhan yang dirasakan hidung tersumbat disertai ingus yang sukar dikeluarkan sejak 1 minggu yang lalu. Hidung dirasakan nyeri bila disentuh, hidung bagian luar tampak mengalami pembengkakan, demam sejak 3 hari tetapi tidak menggigil. Sakit kepala sejak 3 hari. Dahak mengalir di tenggorok tidak ada, terasa berat dan nyeri di sekitar wajah tidak ada. Pasien sebelumnya berobat ke Puskesmas dan diberikan obat tetapi tidak ada perubahan.

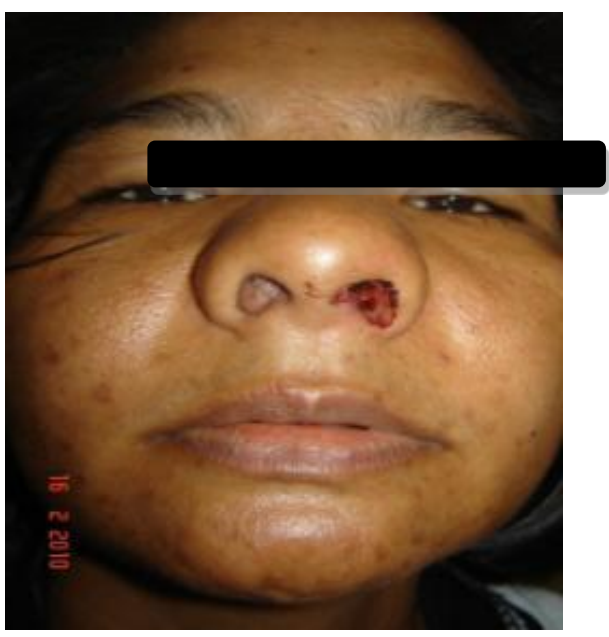

Gambar 4 . Abses septum nasi bilateral saat pasien masuk rumah sakit

Pasien tidak ada riwayat trauma pada hidung, riwayat bersin-bersin tidak ada, riwayat sakit gigi tidak ada dan riwayat DM tidak ada. Riwayat sering mengorek-ngorek hidung ada.

Pada pemeriksaan fisik keadaan umum baik, suhu $37,8^{\circ} \mathrm{C}$. Pada pemeriksaan rinoskopi anterior, kavum nasi dextra dan sinistra tampak sempit, terdapat pembengkakan septum nasi bilateral dengan permukaan licin, berwarna kemerahan. Terdapat nyeri tekan dan fluktuasi pada pembengkakan tersebut. Pemeriksaan telinga dan tenggorok tidak ditemukan kelainan.

Ditegakkan diagnosis kerja abses septum nasi bilateral. Selanjutnya dilakukan aspirasi pada sisi kiri abses septum nasi, keluar pus 1,5 cc. Dilakukan pemeriksaan kultur dan tes sensitifitas. Hasil laboratorium darah, Hemoglobin $12,8 \mathrm{gr} \%$, leukosit $10.900 / \mathrm{mm}^{3}$, hematokrit $39 \%$, trombosit $190.000 / \mathrm{mm}^{3}$, PT 11,4 detik, APTT 39,7 detik, gula darah sewaktu $138 \mathrm{mg} / \mathrm{dl}$.

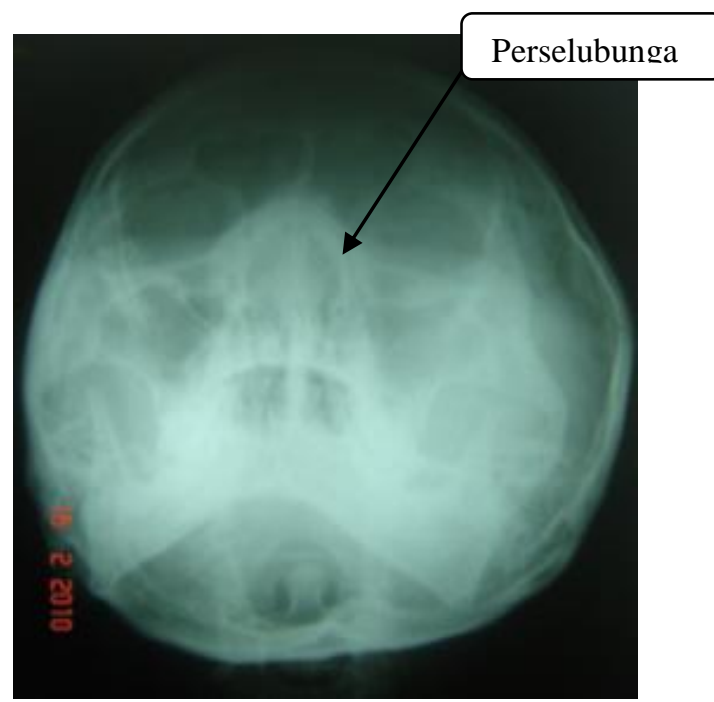

Gambar 5 . Foto Rontgen SPN posisi waters

Pada pemeriksaan foto waters tampak perselubungan pada kavum nasi bilateral. Tidak tampak perselubungan pada sinus maksilaris kanan dan kiri. Tidak ada perselubungan pada sinus frontalis. Tidak tampak deviasi septum nasi. Kesan perselubungan pada kavum nasi mendukung gambaran abses septum nasi.

Pasien dianjurkan dirawat. Tanggal 17 Februari 2010 dilakukan tindakan insisi dan eksplorasi abses septum nasi. Pasien terbaring di meja operasi dengan anestesi umum. Dilakukan asepsis dan antisepsis daerah operasi dan sekitarnya. Dipasang tampon anterior campuran lidokain dan epinefrin 4:1, ditunggu 10 menit. Kavum nasi dievaluasi dengan telescope $0^{\circ}$, tidak dapat dinilai karena kavum nasi tampak sempit. Dilakukan insisi hemitransfiksi pada septum nasi sisi kiri, tampak mukosa septum nasi menebal sehingga insisi diperdalam. Dari luka insisi keluar pus lebih kurang $3 \mathrm{cc}$. Pada eksplorasi melalui luka tampak tulang rawan septum $2 / 3$ anterior sudah hancur sehingga tersisa $1 / 3$ posterior dalam keadaan baik dan tidak tampak perforasi septum nasi. Dilakukan kuretase pada dinding abses, kuretase dilakukan sebersih-bersihnya dengan bantuan nasoendoskop kemudian dicuci dengan betadine dan dilanjutkan dengan $\mathrm{H}_{2} \mathrm{O}_{2} 3 \%$. Dilakukan pemasangan drain handscone pada rongga abses septum nasi dan ditampon anterior pada kedua kavum nasi dengan tampon handscone yang berisi kassa. Lalu difiksasi dan diplester. Operasi selesai.

Diberikan Ceftriaxon $2 \times 1$ gr (IV), Metronidazole $3 \times 500 \mathrm{mg}$ (drip), Dexamethasone 3x 5 $\mathrm{mg}$ (IV). Asam mefenamat $3 \times 500 \mathrm{mg}$ (oral)

Follow up hari ke- 1 pasca operasi (18 Februari 2010) pasien merasakan nyeri pada hidung, terasa nyeri kepala, demam tidak ada. Nyeri di bagian mata tidak ada. Kavum nasi tertutup tampon anterior. Tenggorok tidak ada perdarahan aktif mengalir di tenggorok, bekuan darah di dinding faring posterior tidak ada. Follow Up hari ke-2 (19 Februari 2010) keluhan nyeri pada hidung mulai berkurang, demam tidak ada, nyeri kepala tidak ada. Dilakukan pengeluaran drain handscone. Tampon anterior belum dilepaskan. Follow up hari ke-3 (20 Februari 2010) keluhan nyeri hidung tidak ada, nyeri kepala tidak ada. Hasil kultur dan tes sensitifitas menunjukkan Staphylococcus aureus dan antibiotik dari ceftriaxon ditukar dengan Ciprofloxacin 2x200 mg (drip) karena tingkat sensitifitasnya lebih tinggi (positif 2). Follow up hari ke-4 (21 Februari 
2010) keluhan nyeri di hidung tidak ada, nyeri kepala tidak ada, keluhan lain tidak ada. Tampon anterior dibuka. Tampak kavum nasi kanan dan kiri cukup lapang, pembengkakan di septum sudah tidak ada, perdarahan aktif tidak ada. Luka insisi tertutup.

Hasil dilakukan pemeriksaan laboratorium Hemoglobin 13,5 gr/dl dan leukosit $7500 / \mathrm{mm}^{3}$. Pasien dipulangkan pada hari ke-5, dan dianjurkan kontrol ke poliklinik THT. Pasien diberikan obat Ciprofloxacin 2x500 mg.
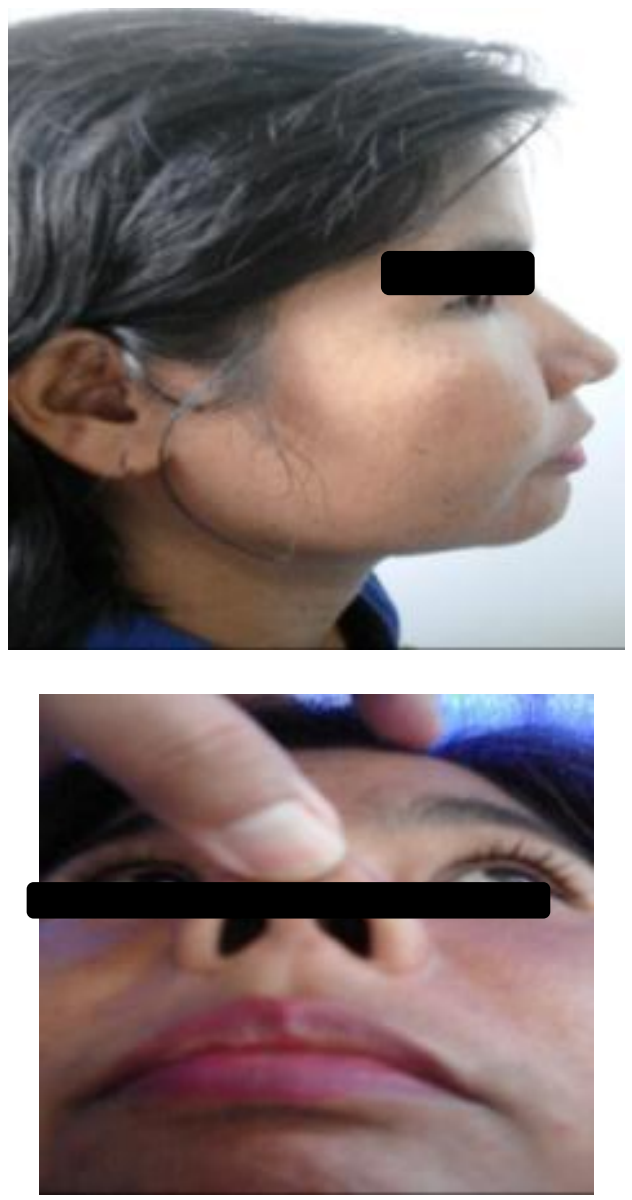

Gbr 6. Pasien Kontrol hari ke-28

Pasien kontrol ke poliklinik THT-KL tanggal 13 Maret 2010 tidak ada keluhan nyeri pada hidung, tidak ada demam, tidak ada nyeri kepala serta tidak ada keluhan yang lainnya. Dari pemeriksaan hidung bagian luar tidak adanya perubahan bentuk hidung seperti hidung pelana (saddle nose). Pemeriksaan rinoskopi anterior dan nasoendoskopi tampak kavum nasi lapang, konka inferior dan konka media eutrofi, tidak ada pembengkakan di kavum nasi. Septum nasi cukup lapang,serta tidak ada perforasi septum nasi.

\section{DISKUSI}

Telah dilaporkan satu kasus abses septum nasi pada seorang wanita usia 34 tahun dan telah menjalani insisi dan drainase serta pemberian antibiotik. Ambrus, dikutip dari Harry Agustaf $^{7}$ melaporkan 16 kasus abses septum nasi dilakukan insisi dan drainase serta pemberian antibiotik.

Kasus ini merupakan kasus yang sangat jarang dimana dari data rekam medik RS M. Djamil Padang hanya didapatkan 3 kasus dalam 2 tahun terakhir.

Diagnosis ditegakkan berdasarkan anamnesis dan pemeriksaan fisik. Gejala abses septum nasi adalah hidung tersumbat yang progresif disertai rasa nyeri. Rasa nyeri terutama dirasakan di daerah dorsum nasi terutama di puncak hidung. Juga terdapat keluhan demam dan sakit kepala. Menurut Canty, dikutip oleh Roytesa ${ }^{14}$, gejala tersering yaitu obstruksi hidung $(95 \%)$, nyeri $(50 \%)$, rinore $(25 \%)$ dan demam (25\%). Hal ini sesuai dengan keluhan utama pasien berupa hidung tersumbat disertai adanya rasa nyeri pada hidung selain itu hidung berlendir dan demam.

Dari pemeriksaan laboratorium didapatkan adanya leukositosis. Demam dan adanya leukositosis hampir $50 \%$ terjadi pada pasien dengan abses septum nasi. $^{12}$

Pada umumnya penyebab utama dikarenakan trauma pada hidung sekitar $75 \%$ kasus dan dilaporkan penyebab abses septum nasi yang lain karena tindakan operasi, benda asing, sinusitis, infeksi pada gigi atau furunkulosis pada hidung. Pada pasien ini disebabkan trauma ringan, karena pasien sering mencabut bulu-bulu hidung. Hal ini sesuai dengan kepustakaan yang menyebabkan abses septum nasi pada umumnya disebabkan oleh adanya trauma pada hidung. ${ }^{12}$

Pemeriksaan dilakukan tanpa menggunakan rinoskopi anterior (inspeksi) tampak adanya pembengkakan bilateral anterior septum nasi. Pada perabaan (palpasi) terasa nyeri pada dorsum nasi. Pemeriksaan secara pasti untuk menentukan abses septum nasi dengan cara aspirasi berupa pus, dan sekaligus pemeriksaan kultur dan sensitifitas untuk mengetahui jenis kuman serta menentukan jenis antibiotik intravena yang tepat. Pada umumnya kuman patogen berupa Streptococcus aureus. Kuman patogen yang lain berupa Streptococcus pneumonia atau Streptococcus viridians, Staphylococcus epidermidis dan Haemophilus influenza. Kuman ini merupakan organisme yang paling sering ditemukan pada kasus-kasus abses septum nasi yang dilaporkan beberapa penulis. ${ }^{12,13}$

Dikutip dari Jalaludin, ${ }^{4}$ Ambrus mendapatkan Stafilokokus aureus sebanyak 44\%, koliform 19\%, Streptokokus beta hemolitikus grup A dan Haemofilus influenza masing-masing $12,5 \%$ sedangkan Fearon mendapatkan Stafilococcus piogen $41 \%$ dan Streptokokus hemolitikus 7,7\%.

Setelah antibiotik diberikan langkah selanjutnya adalah insisi dan drainase abses. ${ }^{2,6}$ Pada pasien ini dilakukan insisi dan drainase dalam anestesi umum.

Penanganan hematoma septum yang terlambat dapat menghambat aliran darah yang merupakan suplai makanan ke kartilago septum, sehingga dapat menyebabkan nekrosis iskemia kartilago septum nasi. Pada kasus ini terjadi perforasi tulang rawan septum $2 / 3$ anterior sudah hancur sehingga tersisa $1 / 3$ posterior dalam keadaan baik dan tidak tampak perforasi septum nasi. ${ }^{12}$

Dikutip dari Cervera, ${ }^{1}$ Cottle sejak tahun 1953 telah memperkenalkan implantasi septum nasi. la menyarankan agar rekonstruksi dilakukan dalam 812 minggu dari terbentuknya abses ketika infeksi mereda.

Dikutip dari Cevera, ${ }^{1}$ Huizing dan beberapa penulis lain beranggapan bahwa rekonstruksi harus dilakukan secepatnya bersamaan dengan drainase atau dalam fase akut untuk memastikan keberhasilan implantasi.

Untuk menghindari komplikasi yang berakibat fatal, maka dokter yang menangani kasus seperti ini harus mempunyai pengetahuan luas mengenai 
patologi, komplikasi dan tindakan rekonstruksinya. ${ }^{2,18}$ Komplikasi yang berat dihubungkan dengan keterlambatan diagnosis, terapi, terjadinya abses septum nasi, destruksi kartilago dan kultur bakteri yang positif. $^{14}$

Pada kasus ini tidak langsung dilakukan rekonstruksi. Follow up untuk terjadinya saddle nose dalam waktu 6 bulan. ${ }^{14}$

\section{Daftar Pustaka}

1. Cervera E.J, Calderón N.R, Enríquez de Salamanca J, Post-traumatic haematoma and abscess in the nasal septa of children. Acta otorinolaryngol.2008;59(3):139-41

2. A George, WK Smith, S. Kumar. Posterior nasal sepal abscess in a healty adult patient.Laryngology and Otology 2008,122,1386-88

3. Pang KP, Sethi DS. Nasal Septal Abscess: unusual complication of acute sphenoethmoiditis. J.Laryngol Otol 2002;116:543-45

4. Jalaludin MAB, Nasal Septal AbscessRetrospective Analysis Of 14 cases from University Hospital, Kuala lumpur. Singapore Med J.1993:34:435-437

5. Maria P.Valencia, Mauricio Castillo. Congenital and Acquired Lesions of the Nasal Septum: A Practical Guide for Differential Diagnosis. Radiographics 2008;28;205-23.

6. David W.E,MD. Emergencies of The Head and Neck,USA,2000

7. Harry Agustaf Asroel. Perforasi Septum Nasi.Dikutip dari www.library.usu.ac.id. Last up dated March,20, 2010.

8. Ballanger, J.J. Penyakit Telinga, Hidung, Tenggorok, Kepala, dan Leher. Binarupa Aksara. Jakarta 1994.1-27
9. Alvarez H, Osorio J, Prim MP, De la Tone C, Gavilan J. Sequelae after nasal septum injuries In children. Int J of ORL \& HNS 2000;27:339-42 www.elsivier.com

10. Dispenza C,Saraniti C,Dispenza F, Caramanna, Salzano FA. Management of nasal septal abscess In Childhood: our experience. Int J.of Ped. Otorhinolaryngology 2004. xxx: 1-5 www.elsivier.com.

11. Dirk J.M, Ivar C.T, Gilbert J.N. Nasal Septal Abscess in Children.Arch Otolaryngology HNS 2008:134:842-43

12. Shih-Hung Lo,MD. Nasal Septal Abscess as a Complication of Laser Inferior Turbinectomy. Chang Gung Med J. 2004:27:390-92.

13. Trimartani, Diany Sawitra, Septorinoplasti: Penanganan Komplikasi Abses Septum akibat trauma. ORL Indonesia 2000:30:21-28.

14. Roytesa R.Savage.Hematoma of the nasal septum. American Academic of Pediatric 2006;27;478-479

15. Bailey BJ. Head and Neck Surgeryotolaryngology. In Karen H.Calhoun.editors. Nasal Obstruction. $3^{\text {rd }}$ ed. Philadelphia Lippincott Williams \& Wilkins;2001.p.293-308.

16. Debnam J.M , Gillenwater A.M. Nasal Septal Abscess in Patient with Immunosuppression. Am.J.Neuroradiol 2007;28: 1878-79.

17. Riechelmann H,Rettinger G. Tree-steps reconstruction of complex saddle nose deformities. Arch Otolaryngol Head Neck Surg 2004;130:334-8.

18. Widiarni $D$, Huizing $E H$. Panduan teknik diseksi septorinoplasti. Bagian THT FKUI/RSCM,2002 Februari 13.

19. Kasperbaver JL,Farer SN,Kern FB. Rekonstructive Surgery of Nasal Septum. In Papel ID editors.Facial Plastic and Reconstructive Surgery.Thieme Medical Publisher,2002:450-59. 